\title{
PENGARUH SISTEM PENGENDALIAN INTERN TERHADAP EFEKTIVITAS PEMBERIAN KREDIT PADA PT. BANK RAKYAT INDONESIA (PERSERO) TBK. CABANG MARISA
}

\author{
Ng Syamsiah \\ Universitas Ichsan Gorontalo \\ Syamsiah_tamsir@yahoo.com
}

\begin{abstract}
ABSTRAK
Tujuan penelitian ini adalah untuk mengetahui dan menganalisis penerapan sistem pengendalian internal pemberian kredit pada PT.Bank Rakyat Indonesia (Persero) Tbk. Cabang Marisa. Dari hasil olahan data SPSS maka diperoleh Olahan data pada program SPSS diperoleh nilai R Square $\left(\mathrm{r}^{2}\right)$ sebesar 0,279 atau 27,90\%. Yang artinya kontribusi sistem pemberian kredit pada PT. BRI cabang Marisa sebesar 27,90\% dan 72,1\% dipengaruhi oleh variabel lain yang tidak diteliti atau diluar dari model. Sedangkan hubungan antara sistem pengendalian intern dengan efektivitas pemberian kredit pada PT. BRI cabang Marisa sebesar 0,528 atau 52,8\%. Yang artinya kontribusi sistem pengendalian intern terhadap efektivitas pemberian kredit yang besarnya $27,9 \%$ dan hubungan keduanya sebesar 0,528 atau 52,8\% adalah signifikan.
\end{abstract}

Kata Kunci: Sistem Pengendalian Intern dan Efektivitas Pemberian Kredit.

\begin{abstract}
The purpose of this study was to determine and analyze the application of the internal control system for providing credit at PT Bank Rakyat Indonesia (Persero) Tbk. Marisa Branch. From the results of the SPSS data processing, it was obtained that the data processing in the SPSS program obtained the R Square (r2) value of 0.279 or $27.90 \%$. Which means the contribution of the credit system at PT. BRI branch Marisa amounted to $27.90 \%$ and $72.1 \%$ influenced by other variables that are not researched or outside the model. Meanwhile, the relationship between the internal control system and the effectiveness of providing credit to PT. BRI branch Marisa amounted to 0.528 or $52.8 \%$. This means that the contribution of the internal control system to the effectiveness of credit extension is $27.9 \%$ and the relationship between the two is 0.528 or $52.8 \%$ is significant.
\end{abstract} Keywords: Internal Control System and Effectiveness of Credit Lending.

\section{PENDAHULUAN}

\section{Latar Belakang Penelitian}

PT. Bank Rakyat Indonesia (Persero) Tbk. merupakan bank pemerintahan yang beroperasi pertama kali di Indonesia. Dalam perkembangannya BRI sudah mengalami beberapa kali perubahan nama dan status yang memiliki kaitan erat dengan sejarah perjuangan bangsa Indonesia. Perubahan-perubahan yang dilakukan BRI tentunya mengandung arti penting bagi perkembangan dan pertumbuhan BRI. Hal ini sejalan dengan cita-cita dan tujuan BRI yang tertuang dalam visi dan misi BRI dalam melayani nasabah.

Aktivitas bisnis merupakan fenomena yang sangat kompleks karena mencakup berbagai bidang diantaranya yaitu hukum, ekonomi, dan politik. Perkembangan 
perekonomian nasional dan perubahan lingkungan strategis yang dihadapi dunia usaha termasuk usaha kecil menengah saat ini sangat cepat dan dinamis. Dalam kehidupan masyarakat dapat dilihat bahwa aktivitas manusia dalam dunia bisnis tidak lepas dari peranan bank selaku pemberi layanan perbankan bagi masyarakat.

Dunia usaha khususnya sektor usaha kecil dan menengah menjadi salah satu potensi yang harus dikembangkan dalam rangka mendorong pencapaian tujuan nasional yang berkaitan dengan peningkatan dan pemerataan hidup masyarakat. Kondisi ini mengharuskan setiap pengusaha baik kecil maupun menengah melakukan upaya demi menstabilkan atau lebih meningkatkan eksistensi usahanya. Salah satu masalah yang umumnya menjadi penghambat adalah masalah permodalan usaha kecil dan menengah.

Berdasarkan uraian diatas, investasi modal adalah masalah yang terus menerus dicari jalan keluarnya oleh pemerintah, sehingga para pengusaha tidak kesulitan mencari modal kerja dalam memulai atau mengembangkan kegiatan usahanya. Bank sebagai badan usaha senantiasa harus diarahkan dan didorong untuk peran sertanya melalui jasa kredit yang sangat dibutuhkan oleh masyarakat.

Ditinjau dari sudut pandang perbankan yang menyediakan sumber dana yang berbentuk perkreditan, maka kredit akan mempunyai suatu kedudukan yang snagat istimewa, terutama pada negara-negara yang sedang berkembang sebab antara volume permintaan akan dana jauh lebih besar dari penawaran dana yang ada di masyarakat. Akibat selanjutnya dapat dilihat bahwa pendapatan bunga dari kredit merupakan komponen yang dominan di bandingkan dengan pendapatan jasa-jasa perbankan lainnya. Dan sebaliknaya berlainan apabila dilihat pada neraca dan laporan perhitungan rugi/laba pada bank-bank dari negara maju komponen pendapatan bunga sudah mempunyai kedudukan yang seimbang dengan pendapatan jasa-jasa dari perbankan lainnya.

Namun walaupin demikian, sektor perkreditan tetap merupakan kegiatan yang penting dari suatu industri perbankan baik di negara-negara sedang berkembang maupun pada negara-negara yang telah maju, karena kredit sebagai salah satu sumber dana yang penting dari setiap jenis kegiatan usaha.

Bank Rakyat Indonesia (BRI) merupakan salah satu bank pemerintah yang telah berubah statusnya menjadi PT (persero), masih berperan serta secara aktif dalam pembangunan nasional dengan menyediakan pelayanan dalam jasa perbankan bagi seluruh lapisan masyarakat. Salah satu bentuk pelayanan perbankan yang di berikan oleh BRI adalah di bidang perkreditan dengan sasaran utama pengusaha kecil dan menengah ke atas. Pada umumnya kredit yang diberikan berupa kredit modal kerja. Kredit jenis ini biasanya di peruntukan bagi calon nasabah yang ingin memulai suatu usaha baru atau bagi nasabah yang ingin mengembangkan usahanya. Mengingat persaingan yang terjadi di antara bank-bank yang ada maka di dalam pelayanan pemberian kredit ini BRI menetapkan suatu sistem pengendalian intern dan prosedur pemberian kredit yang bertujuan untuk mempermudah nasabah dalam melakukan peminjaman.

Istilah kredit berasal dari bahasa yunani, yaitu "credere" yang berarti kepercayaan. Makna dari kata kredit tersebut menunjukan bahwa dasar dari pemberian kredit adalah berdasarkan kepercayaan. Kepercayaan ini berarti bahwa seseorang atau badan yang memberikan kredit (kreditur) percaya bahwa penerima kredit (debitur) dikemudian hari sanggup untuk memenuhi segala sesuatu yang telah menjadi perjanjian diantara kedua belah pihak. Alasan seseorang memerlukan kredit, yaitu karena manusia selalu berusaha untuk memenuhi kebutuhan yang bermacam-macam sedangkan kemampuan untuk 
mencapai sesuatu yang diinginkan sangat terbatas. Hal tersebut menyebabkan manusia memerlukan bantuan untuk memenuhi hasrat dan cita-citanya. Maka dari itu, untuk mrningakatkan usahanya, manusia memerlukan bantuan dalam bentuk permodalan yang di sebut dengan kredit.

Pada BRI Cabang Marisa salah satu permasalahnya adalah kredit macet dimana suatu keadaan nasabah sulit ditagih atas kredit yang diberikan bank atau telah disepakati sebelumnya antara pihak bank dan nasabah. Untuk menghindari adanya kredit macet, perusahaan harus mengantisipasi dari sejak pengajuan kredit oleh nasabah sampai pelunasan kredit. Bank perlu memberikan penilaian terhadap nasabah yang mengajukan kredit pinjaman serta merasa yakin bahwa nasabah nya mampu mengembalikan kredit yang diterimanya. Masalah keamanan atas kredit yang diberikan merupakan masalah yang harus diperhatikan oleh bank, karena adanya resiko yang timbul dalam sistem pemberian kredit. Fasilitas pemberian kredit yang diberikan bank merupakan aset terbesar bagi bank. Oleh karena itu, pengelolaan dan pengawasan pemberian kredit harus dilakukan sesuai dengan prosedur yang memadai demi keamanan.

Proses pemberian kredit dilakukan dengan menerapkan prinsip kehati-hatian agar fasilitas kredit yang diberikan tepat sasaran. Pemberian kredit harus dilaksanakan sesuai dengan kebijakan-kebijakan yang sudah ditetapkan bank. Kebijakan bank tersebut antara lain melakukan penilaian kelayakan terhadap calon debitur. Hal ini dilakukan untuk mempertimbangkan risiko-risiko yang akan terjadi termasuk kemungkinan timbulnya kredit macet. Kelancaran penyaluran kredit sangat tergantung peranan bank itu sendiri dan kesadaran pihak debitur untuk menyelesaikan kredit sebagaimana yang telah disepakati. Dengan adanya prosedur penyaluran kredit yang efisien dan efektif diharapkan kebutuhan nasabah dapat terpenuhi dan risiko kegagalan kredit menjadi kecil. Masalah keamanan atas kredit yang diberikan merupakan masalah yang harus diperhatikan oleh bank, karena adanya risiko yang timbul dalam sistem pemberian kredit. Permasalahan ini bisa dihindari dengan adanya suatu pengendalian intern yang memadai dalam bidang perkreditan. Dengan kata lain diperlukan suatu pengendalian intern yang dapat menunjang efektivitas sistem pemberian kredit. Sistem dan prosedur yang dapat menunjang keamanan proses berjalanya sistem pengendalian intern pemberian kredit yaitu dengan melalui formulir-formulir yang memadai, catatan-catatan dan prosedur yang mendukung efektivitas suatu sistem pengelolaan kredit. Kreditur juga berkepentingan terhadap laporan keuagan dari perusahaan yang telah atau akan menjadi debitur untuk keamanan mereka sendiri dengan menganalisa terlebih dahulu terhadap laporan keuangan dari perusahaan tersebut dalam membayar kembali hutangnya ditambah beban bunga. Untuk menghindari dan meminimalkan kredit yang bermasalah maka diperlukan adanya kontrol yang baik dari perusahaan terhadap prosedur pemberian fasilitas kredit.

Pengendalian intern pada BRI Cabang Marisa adalah suatu proses yang dilaksanakan oleh dewan direksi, manajemen, dan personel lainnya dalam suatu entitas, yang dirancang untuk menyediakan keyakinan yang memadai berkenaan dengan pencapaian tujuan Bank. Berdasarkan pengertian tersebut, dapat diketahui bahwa pengendalian intern merupakan komponen penting dalam manajemen bank dan menjadi dasar bagi kegiatan operasional bank. Terselenggaranya sistem pengendalian intern bank yang sehat dan efektif menjadi tanggung jawab dari semua pengurus dan para pejabat bank. Pengendalian intern perlu mendapat perhatian khusus mengingat bahwa salah satu faktor penyebab terjadinya kesulitan usaha bank adalah berbagai kelemahan dalam pelaksanaan sistem pengendalian 
intern bank. Pengendalian intern yang memadai pada dasarnya bertujuan untuk melindungi harta milik organisasi dengan meminimalkan kemungkinan terjadinya penyelewengan, pemborosan, kredit macet, serta meningkatkan efisiensi dan efektivitas kerja. Dengan pengendalian internal yang memadai diharapkan dapat menjamin proses pemberian kredit tersebut akan dapat terhindar dari kesalahan dan penyelewenganpenyelewengan.

Bank harus benar-benar memperhatikan sistem pengendalian intern dalam pemberian fasilitas kredit sehingga resiko akan adanya kredit yang bermasalah dapat di perkecil. Kredit yang bermasalah ini dapat mengganggu kelancaran usaha bank yang tentunya dapat menimbulkan krisis kepercayaan dari masyarakat. Dengan terselenggaranya sistem pengendalian intern yang memadai, terutama dalam bidang perkreditan berarti menunjukan sikap kehati-hatian bank dalam menjaga kepercayaan diri masyarakat dan dalam menjaga kelangsungan hidup usahanya.

\section{METODOLOGI PENELITIAN}

\section{Jenis dan Sumber Data Jenis Data}

Jenis data yang digunakan dalam penelitian ini adalah data kualitatif, yaitu data yang terdiri dari data non angka yang bersifat deskriptif, berupa gambaran umum perusahaan, struktur organisasi perusahaan, visi dan misi, serta data-data lain yang dibutuhkan oleh penulis dalam penelitian ini.

\section{Sumber Data}

Sumber data adalah fakta atau keterangan yang dapat di pertanggung jawabkan kebenarannya. Sebagian besar tujuan dari penelitian adalah memperoleh data yang relevan, dapat dipercaya dan dapat di pertanggung jawabkan. Dalam penelitian ini, Penulis mencari data-data yang dibutuhkan yaitu berupa data primer dan data sekunder:

\section{a. Data Primer}

Data ini diperoleh langsung dari penelitian lapangan dengan pengamatan langsung pada PT Bank BRI (Persero)Tbk.Cabang Marisa yang menjadi objek penelitian serta mengadakan wawancara langsung dengan bagian-bagian terkait, seperti Pimpinan Cabang, Internal Control,Marketing Lending Officer (MLO), Bagian Kredit.

b. Data Sekunder

Data sekunder adalah data tidak langsung yang dapat dijadikan sebagai informasi tentang teori dan konsep di bidang masing-masing,sehingga relevan dengan pembahasan yang diteliti, dimana data sekunder ini dapat diperoleh dari studi kepustakaan,mempelajari berbagai literatur, atau mempelajari hasil-hasil penelitian pustaka.

\section{Populasi}

Menurut Sugiyono (2012:61) populasi adalah wilayah generalisasi yang terdiri atas obyek/subyek yang mempunyai kualitas dan karakteristik tertentu yang di tetapkan oleh peneliti untuk dipelajari dan kemudian ditarik kesimpulannya. Populasi dalam penelitian 
ini adalah seluruh karyawan PT. Bank Rakyat Indonesia (Persero) Tbk Cabang Marisa yang berjumlah 30 0rang.

\section{Uji Validitas}

Sebuah instrument penelitian dikatakan valid, jika mampu mengukur apa yang diinginkan dan dapat mengungkapkan data dari variabel yang diteliti secara tepat. Dalam analisis ini (Sugiono, 2001:124) memberikan interpretasi terhadap koofisien korelasi yang menyatakan bahwa item yang mempunyai korelasi positif dengan kriterium skor total serta korelasi yang tinggi menunjukkan bahwa item-item tersebut mempunyai validitas yang tinggi pula. Hasilnya dibandingkan dengan nilai kritis pada tingkat signifikan 5\% $(\mathrm{a}=0,05)$. Jika koofisien korelasi lebih besar dari nilai kritis maka alat ukur tersebut dikatakan valid. Jika koefesien korelasi lebih besar dari pada nilai kritis maka alat ukur tersebut valid atau reliabel.

\section{Uji Reliabilitas}

Uji reliabilitas digunakan untuk melihat sejauh mana suatu instrumen yang bila digunakan beberapa kali untuk mengukur objek yang sama, akan menghasilkan data yang sama. Di dalam pengujian reliabilitas penulis menggunakan metode koefisien alpha cronbach.

Kemudian dilakukan pengumpulan dan pengolahan data yang diperoleh dari kuesioner dengan cara memberikan bobot penilaian dari setiap item pertanyaan system pengendalian intern dan efektivitas pemberian kredit berdasarkan skala likert.

Untuk pengolahan data yang digunakan alat bantu statistik dimana dengan alat tersebut dapat memudahkan penafsiran untuk menganalisa apakah ada hubungan antara variabel $\mathrm{X}$ dengan variabel $\mathrm{Y}$ serta seberapa besar pengaruhnya yang akhirnya akan diperoleh suatu pedoman untuk menarik kesimpulan.

\section{Metode Analisis Data}

Setelah data diambil selanjutnya dianalisis untuk melihat gambaran hasil penelitian dan menguji hipotesis yang diajukan. Penggambaran hasil penelitian ini dapat dilihat dari mean, standart deviasi dan variansnya, sedangkan pengujian hipotesis digunakan analisis regresi linear sederhana.

Untuk menguji hipotesis dalam penelitian ini digunakan analisis regresi sederhana. Adapun Persamaan regresi digunakan untuk memprediksi bentuk pengaruh sistem pengendalian intern dan efektivitas pemberian kredit yaitu dengan rumus yang digunakan adalah: $\mathbf{Y}=\mathbf{a}+\mathbf{b x}$

\section{Pembahasan Hasil Penelitian}

\section{Analisis Regresi}

Berdasarkan pada hasil olahan data dengan menggunakan program SPSS maka diperoleh hasil persamaan regresi $Y=8,646+\mathbf{0 , 1 5 1 X}$

\section{Coefficients(a)}




\section{AkMen}

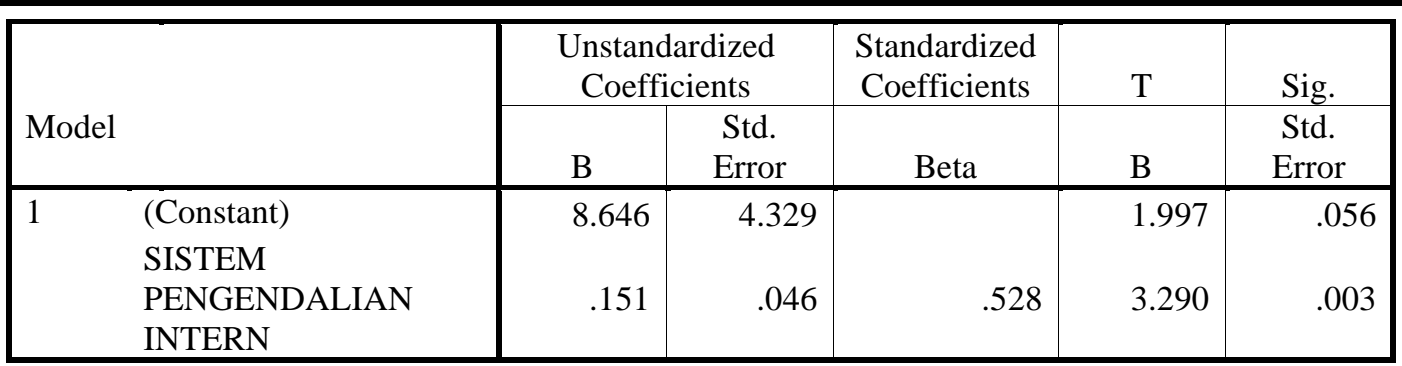

a Dependent Variable: EFEKTIVITAS PEMBERIAN KREDIT

Dari hasil olahan data SPSS maka diperoleh persamaan regresi sederhana dimana nilai constant 8,646 yang berarti jika niali constant diabaikan dalam hal ini efektivitas pemberian kredit pada PT. BRI cabang Marisa, maka efektivitas pemberian kredit sebesar 0,151 yang juga dijadikan tolak ukur. Yang artinya setiap peningkatan satu satuan efektivitas pemberian kredit, maka efektivitas pemberian kredit pada PT. BRI cabang Marisa mengalami peningkatan sebesar 0,151 satuan.

\section{Uji Validitas}

Uji validitas adalah metode analisis yang digunakan untuk mengukur besarnya korelasi antar variabel independen dengan variabel dependen.

\section{Model Summary}

\begin{tabular}{|c|c|c|c|c|c|c|c|c|c|}
\hline Model & $\mathrm{R}$ & $\begin{array}{c}\mathrm{R} \\
\text { Square }\end{array}$ & $\begin{array}{l}\text { Adjuste } \\
\text { d R } \\
\text { Square }\end{array}$ & $\begin{array}{l}\text { Std. Error } \\
\text { of the } \\
\text { Estimate }\end{array}$ & & Cha & ge Statist & & \\
\hline & $\begin{array}{c}\mathrm{R} \\
\text { Square } \\
\text { Change } \\
\end{array}$ & $\begin{array}{c}\mathrm{F} \\
\text { Change } \\
\end{array}$ & df1 & df2 & $\begin{array}{l}\text { Sig. F } \\
\text { Change }\end{array}$ & $\begin{array}{c}\mathrm{R} \\
\text { Square } \\
\text { Change } \\
\end{array}$ & $\begin{array}{c}\mathrm{F} \\
\text { Change }\end{array}$ & df1 & df 2 \\
\hline 1 & $.528(\mathrm{a})$ & .279 & .253 & 1.29858 & .279 & 10.822 & 1 & 28 & .003 \\
\hline
\end{tabular}

a Predictors: (Constant), SISTEM PENGENDALIAN INTERN

Olahan data pada program SPSS diperoleh nilai R Square $\left(\mathrm{r}^{2}\right)$ sebesar 0,279 atau 27,90\%. Yang artinya kontribusi sistem pemberian kredit pada PT. BRI cabang Marisa sebesar $27,90 \%$ dan $72,1 \%$ dipengaruhi oleh variabel lain yang tidak diteliti atau diluar dari model. Sedangkan hubungan antara sistem pengendalian intern dengan efektivitas pemberian kredit pada PT. BRI cabang Marisa sebesar 0,528 atau 52,8\%. Jika dibandingkan dengan Interprestasi koefisien korelasi nilai $\mathrm{R}$ maka masuk dalam kategori sedang.

\section{Uji Reliabilitas}

Uji reliabilitas digunakan untuk menguji kelayakan atau signifikansi suatu penelitian. Untuk menguji signifikansi dengan menggunakan nilai $\alpha=5 \%$ dengan tingkat kebeasan (df)n -2 yaitu $30-2=28$.

ANOVA(b)

\begin{tabular}{|l|c|c|c|c|c|}
\hline Model & $\begin{array}{c}\text { Sum of } \\
\text { Squares }\end{array}$ & Df & Mean Square & F & Sig. \\
\hline
\end{tabular}




\begin{tabular}{|ll|r|r|r|r|r|}
\hline 1 & Regression & 18.250 & 1 & 18.250 & 10.822 & $.003(\mathrm{a})$ \\
& Residual & 47.217 & 28 & 1.686 & & \\
Total & 65.467 & 29 & & & \\
\hline
\end{tabular}

a Predictors: (Constant), SISTEM PENGENDALIAN INTERN

b Dependent Variable: EFEKTIVITAS PEMBERIAN KREDIT

Hasil olahan data dengan menggunakan SPSS dapat diperoleh F hitung sebesar $10.822>$ sig. sebesar 0,003 berarti Ho ditolak dan Ha diterima yang artinya secara parsial kontribusi sistem pengendalian intern terhadap efektivitas pemberian kredit yang besarnya $27,9 \%$ dan hubungan keduanya sebesar 0,528 atau $52,8 \%$ adalah signifikan. Kontribusi sistem pengendalian intern terhadap efektivitas pemberian kredit pada PT. BRI cabang Marisa sebesar 27,9\% sedangkan 72,1\% dipengaruhi oleh variabel lain selain pelatihan atau variabel yang tidak diteliti.

\section{KESIMPULAN DAN SARAN}

\section{Kesimpulan}

Berdasarkan hasil penelitian dan pembahasan dapat ditarik kesimpulan bahwa kontribusi sistem pengendalian intern terhadap efektivitas pemberian kredit pada PT. BRI cabang Marisa berpengaruh positif dan signifikan sebesar 52,8\%.

\section{Saran} kepada :

Berdasarkan hasil penelitian dan pembahasan hasil penelitian, maka disarankan

1. Pihak manajemen PT.BRI cabang Marisa agar kiranya memperhatikan sistem pengendalian intern dalam hal pemberian kredit kepada nasabahnya.

2. Diharapkan kepada peneliti selanjutnya agar meneliti variabel lain yang dapat mempengaruhi efektivitas pemberian kredit khususnya yang meneliti di perbankan.

\section{DAFTAR PUSTAKA}

Amanina, Ruzana. 2011. Evaluasi terhadap sistem pengendalian internal pada proses pemberian kredit mikro (studi pada PT Bank Mandiri (PERSERO) tbk. cabang majapahit. Semarang. Skripsi. Semarang: Fakultas Ekonomi Universitas Diponegoro.

Ahmad, Amira. 2013. Tinjauan Efektivitas Penerapan Sistem Pengendalian Internal Pemberian Kredit Pada PT. Bank Mega Cabang Makassar. Skripsi tidak diterbitkan. Makassar: Jurusan Akuntansi Fakultas Ekonomi dan Bisnis Universitas Hasanuddin. 


\section{AkMen}

Dwi Rizaly, Pahlevi. 2016. Tinjauan efektivitas penerapan sistem pengendalian intern pemberian kredit pada PT. Bank ABC. Skripsi tidak di terbitkan. Makassar: Jurusan Akuntansi Fakultas Ekonomi dan Bisnis Universitas Hasanuddin.

Mulyadi. 2002. Auditing, Edisi 6. Jakarta: Salemba Empat

Al Haryono Jusuf. 2001. Dasar - Dasar Akuntansi Jilid 2. Yogyakarta: STIE YKPN.

Boynton, William C. Raymond N. Johnson. Walter G.Kell. 2003. Modern Auditing,Edisi Tujuh. Ahli Bahasa Paul A, Gina, Gania, IchsanSetito Budi. Jakarta: Erlangga

Widjaja tunggal, Amin. 1995. Struktur Pengendalian Intern. Jakarta: Aneka Cipta Untung, Budi.2000. Kredit Perbankan di Indonesia. Yogyakarta: Penerbit Andi

Kasmir. 2002. Bank dan Lembaga Keuangan Lainnya. Jakarta: Raja Grafindo Persada

Kasmir. 2012. Manajemen Perbankan. Jakarta: Raja Grafindo Persada

Handayaningrat, Soewarno. 2002, Pengantar Studi Ilmu Administrasi dan Manajemen. Jakarta: PT. Toko Agung.

Komarudin. 2000. Ensiklopedia Manajemen. Jakarta: Bumi Aksara.

Mahmudi. 2008. Manajemen Kinerja Sektor Publik. Edisi Kedua. Jakarta: UPP

Hasibuan, Malay S.P. 2006. Dasar-dasar Perbankan, Cetakan Kelima. Jakarta: PT. Bumi Aksara.Jakarta: Erlangga.

Sugiyono.2012. Statistika Untuk Penelituan. Bandung: Penerbit Alfabeta

Umar, Husain. 2002. Metode Riset Bisnis. Jakarta: PT. Gramedia Pustaka Utama

Handayaningrat, Soewarno. 2002, Pengantar Studi Ilmu Administrasi dan Manajemen. Jakarta: PT. Toko Agung.

Komarudin. 2000. Ensiklopedia Manajemen. Jakarta: Bumi Aksara.

Mahmudi. 2005. Manajemen Kinerja Sektor Publik. Edisi Kedua. Jakarta: UPP 